\title{
Science and Technology Policy Reforms in China - A Critical Assessment
}

\author{
ERIK BAARK and LIU SUYING
}

The last decade has been a period of stock-taking and new adventures for Chinese policies regarding science and technology. After the new leadership had established itself in the late 1970s, and it looked back on the achievements and the mistakes of previous years, there was a strong feeling of frustration with the fact that levels of technology in China continued to lag behind advanced countries. To inject vitality into what seemed to be a dormant, but potentially powerful, science and technology (S\&T) system required reforms which, in many respects, were more radical than anything of the past.

We have witnessed a process where the results of research appeared for sale on a market, where scientists became engaged as »moonlighting « consultants, and where private research units have become fashionable. At the same time, however, these reforms have provided fascinating insights into the structural barriers which exist for technological innovation in modern Chinese society. In many respects, the exposure of such barriers provides crucial clues to the formulation of better S\&T policies in China.

With this paper we hope to contribute to a critical assessment of the reforms. We are concerned with the political support of the S\&T policy reforms. The S\&T system established after 1949 on the basis of a Soviet model appears to have recovered quickly after the alledgedly shattering onslaughts of ideological anti-intellectualism during the Cultural Revolution. The scientists had barely drawn a sigh of relief before new, »marketoriented «forces were let loose on them in the 1980s. The final years of the decade have brought about a stalemate between the push for commercialization and the resistence to change. Who were the main proponents of the sold « system, and who were politically motivated to develop the new approaches? We shall provide a brief analysis of competing models in the politics of science and technology management which we hope will clarify these questions.

Our main concern is, however, an attempt to gauge the actual impact of the reforms. We shall look at three areas where commercialization was 
supposed to generate dynamism. First, the breaking the "iron rice bowl « of research funding was intended to achieve a more efficient and productive allocation of money. Secondly, people were to be relieved of the shackles of centrally managed assignment to permanent posts. With opportunities to move into new jobs scientists were expected to make full use of their talents. Thirdly, technology-based entrepreneurship was promoted as a new means of diffusion. The emergence of a large number of collectively owned or private high technology ventures in the vicinity of institutions of higher education and research raised many controversial issues of how far commercialization should go.

\section{The Politics of Science and Technology}

It is notoriously difficult to analyze the role of different political views concerning S\&T in China, and to identify concretely the personalities or political factions that are supporters of such views. Throughout the history of the PRC, issues related to S\&T priorities have been intimately connected with national defence or economic security, which are guarded by secrecy in the interests of the state. In addition the Chinese Communist Party (CCP) has traditionally maintained a strong reluctance towards conducting policy discussions in public. Consequently, most new policy initiatives are announced as directives rather than as proposals open to debate.

We propose, however, that there have been two major themes in S\&T policy debates in China - themes that have been characterized by rather different concerns and modes of political action. The main theme during much of the history of the PRC has been the status of scientists as an intellectual elite and their ideological consciousness. The other theme deals with the management of science and technology, centering on the processes of decision-making and the implementation of concrete priorities.

\section{Ideological Consciousness}

The theme of ideological consciousness was largely dictated by a rather abstract concept of proletarian science and the allegiance of Chinese scientists to the current priorities of the Chinese Communist Party. This theme dominated political debate up until the 1980s, forming rival camps of what we would designate ideologists $«$ and $»$ neutralists. ${ }^{1}$ 
The ideologist camp, under the influence of Mao Zedong, stressed total allegiance to the party and Marxist-Leninist philosophy. During the AntiRightist Campaign of 1956, the Hundred Flowers Campaign and the Cultural Revolution, Mao Zedong took an active interest in the activities of China's scientists, which he had otherwise largely ignored. He and his followers required scientists to develop their ideological consciousness, to let the interests of the people dictate research priorities. The concrete policy implications of these ideas remained elusive, however, and the evidence which has been published since 1976 suggests that the main effect was a coercion of the vast majority of eminent scientists and an almost complete disruption of formal S\&T activities. Only key projects of vital importance to national defence characteristically appeared to be shielded from the devastating activities of the Red Guards.

The neutralist camp, we feel, can be characterized by the views expressed by Deng Xiaoping, the dominant personality of the Post-Mao leadership, who believed that the results of science and technology were neutral. Accordingly, it did not matter whether "the cat is black or white, as long as it catches mice, " and the neutralist view was simply concerned with ensuring the production of results. During most of the first three decades after 1949 the neutralist approach dominated S\&T policy and management, and China simply emulated the Soviet model. This in cluded the expansion of the Chinese Academy of Sciences (CAS) into a central research organization and the establishment of a range of research units for individual sectors of the society. The Soviet model seemed well suited to mobilize S\&T forces on sharply confined projects of national priority, e.g., nuclear weapons, missiles, or hybrid rice. In fact, most major Chinese achievements have occurred in such projects.

Zhou Enlai was the primary force behind the concrete formation of the neutralist S\&T policy during the early years of the PRC. In taking this special interest in the utilization of intellectuals, and the planning and coordination of civilian research, Zhou Enlai created a tradition for the State Council to occupy a key position in policy-making in this sector. Simultaneously the defence sector was rapidly creating its own network of scientific and technological institutions, led by another influential "grand old man « of Chinese S\&T politics, Nie Rongzhen. In this process the defence system (including space S\&T) appears to have captured a lion's share of the financial resources and talented scientists, including famous overseas Chinese scientists such as Qian Xuesen who eventually returned to China. 


\section{Institutional Interests}

The second major theme has been concerned with efficiency in the management of science and technology, centering on the role of centralized decision-making. Rival positions in the debate on this theme, which has dominated the 1980s, tend to be dictated by institutional interests. In the course of the 1980s, we suggest that three new positions have fought for influence; for convenience, we shall label these models «bureaucratic, " "scientistic, " and "economistic, " although the actual political interests of each view have been far more complex, and frequently overlapping, than what such labels imply. One should also note that these three new views emerged as transformations of the neutralist approach, while the ideologist view has all but disappeared from the political scene. Ideologist rhetoric has, however, reemerged in the form of the »Four Cardinal Principles « lately, primarily for the purpose of weeding out opposition to the party's political rule and the priorities of the military-state complex.

The bureaucratic model is thus based on the institutional interests of the military-state economic complex. In adopting the Soviet approach to institution-building and planning of science and technology, China created an elaborate network of sectorial research academies and institutes serving the ministries of machine-building, which had major responsibilities for undertaking defence-related $\mathrm{R} \& \mathrm{D}{ }^{2}$ During this period the Chinese also created a tradition of large projects pursued through a centralized planning process. In addition to the two long-term plans for S\&T development formulated in 1956 and 1978 respectively, and both of which were revised substantially due to shifting political priorities, the bureaucratic model has permeated the formulation and implementation of scientific and technological projects under the five-year plan cycle. ${ }^{3}$

In a way similar to its neutralistic precedent, the bureaucratic model has adhered to the belief that the research system formed a contingent of specialized "workers « which should - and could - make substantial contributions to China's socialist economic development, a belief that was endorsed in Deng Xiaoping's speech at the National Science Conference in March 1978. This speech is now seen as the turning-point in Chinese S\&T policy. ${ }^{4}$

The speech marked a final showdown for the ideologists, but hardly touched upon the issue of effective management. Instead, the conference passed the "Outline National Plan for the Development of Science and Technology 1978-1985 (draft).« This document was conceptually tied up 
with bureaucratic resurgence, and indeed directly linked to the ambitious 10- year economic plan unveiled by Hua Guofeng. The plan proposed ambitious targets and approved of 38 major science and technology projects in eight fields, such as agriculture, energy, raw materials, computer science, lasers, space, high energy physics and genetic engineering. The plan was very expensive and turned out to be difficult to implement with the limited human and financial resources available in China. In a manner typical for the bureaucratic approach, however, the prestigeous projects envisaged in the plan served to raise nationalist ambitions and attract international attention. The plan relied on the concepts and organizational characteristics of the Soviet model as incorporated in the Chinese S\&T planning system developed during the first thirty years.

At this stage Deng Xiaoping appears to have been a champion of the scientistic model too, as he supported the idea that scientists were inherently capable of conducting and disseminating useful research results, once they were left to decide their own priorities. This was a characteristic expression of the traditional views of the scientific community of China, and the rehabilitated scientists now began to lobby for larger financial resources for research. ${ }^{5}$ As a prominent example, the Chinese Academy of Sciences regained its original status as a centre of natural sciences, and was once again given control of many institutes which had been transferred to the local government or simply dissolved during the Cultural Revolution. Similarly, the China Association for Science and Technology revived its activities in the area of science popularization and professional debates. The end of the 1970 s thus led to the formation of a scientistic lobby which, initially at least, supported the existing Soviet-type S\&T management system together with the military-state complex.

The economistic model developed largely in response to the apparent failure of civil research and development, but also in reaction to the political influence of these lobbyist groups. With the support of technocrats which had recently gained more influence on the direction of research, this view posed the most serious challenge to the old system. At the national level, these technocrats became more powerful at the State Science and Technology Commission (SSTC) which had been reestablished and provided with power to coordinate and set up comprehensive policies. This move was accompanied with several other organizational changes. For instance, provincial science and technology commissions were established to oversee the large number of local research institutes that had 
been created since the 1950s. In this process, the priorities set up for the 8-year plan by prominent scientists and their political lobbyists at the Communist Party appear to have been questioned. In the spirit of the new pragmatism after the Third Plenum of the Eleventh Central Committee in December 1978, it soon became an axiom that science should be directed by economic priorities.

The economistic position emphasized new criteria for the management of research that were based on entrepreneurship at the lower levels of the S\&T system. Their support base was erected on the philosophy of marketoriented reforms, which had been confirmed by new experiments with contract research. For Zhao Ziyang the successful experiences of the few institutes which had been involved, emphasizing effectiveness in the diffusion of results, demand-oriented research priorities and other features which became very prominent in the 1980s, encouraged reforms which were in almost direct opposition to the centralized planning philosophy of the militarists and the expansionist tendencies of the scientistic position.

In December 1980 this economistic position was developed into a pragmatic program at the National Conference on Science and Technology Work. On the base of discussions at the Conference, the party committee at the SSTC drew up "Outline Report on Policy concerning the Development of our National Science and Technology, « which was approved in April 1981 by the CCP Central Committee and the State Council. The Outline summarized the future directions for science and technology policy in five major points:

1. Science and technology was to be developed in coordination with society and economy with the primary mission of promoting economic development.

2. Applied research on production technology and products was to be strengthened, shifting the balance towards a more useful structure of technological development.

3. Research and development activities in production enterprises were to be stepped up.

4. Basic research was to be guaranteed a position and to be expanded steadily.

5. Imports of foreign technology was to be based on the national economic requirements. 
In September 1982, at the Twelfth Party Congress, Hu Yaobang reiterated the axiom that science and technology was a key to the realization of the Four Modernizations. On October 24 in 1982 Zhao Ziyang addressed the National Conference for Scientific Awards, and here made an attempt to define more precisely the relationship between science, technology and economic development. He put forward the slogan that seconomic construction should rely on the development of science and technology, and they in return should be geared to the needs of economic construction. « This slogan became a kind of programmatic base of Zhao Ziyang's efforts to wrest something useful out of the existing S\&T system.

An emphasis on the requirements of the economy served the economistic camp primarily as a political weapon to shoot down ill-advised, prestigeous projects in fields such as high-energy physics. The new directions occurred simultaneously with criticism of expensive and politically biased projects such as the Baoshan Steelworks. The financial cutbacks on expensive accelerator projects was also much in the same vein as the disillusion over the actual weakness of China's economic strength. It was most controversial for people engaged in basic science, for instance the most eminent scientists in the Chinese Academy of Sciences. These scientists - the core of the scientistic lobby - remained antagonistic to reforms which stressed applied research and tangible, immediate results at the expense of basic research.

There are reasons to believe that they were supported in this resistance to the reforms by $\mathrm{Hu}$ Yaobang, who had been President of the Academy during a short spell in the 1970s. At any rate, a new President of the Chinese Academy of Sciences, Lu Jiaxi, who was elected in 1981, was removed from his post in January 1987 when $\mathrm{Hu}$ Yaobang fell from power. This dismissal was probably a consequence of the backlash of political pursuasion which was intended to put an end to the demands expressed by dissidents such as Fang Lizhi, towards whom Lu Jiaxi was clearly perceived as being too indulgent. But for all the rhetoric concerning commitments to reform that were expressed by Lu Jiaxi in his speeches on the new role and organization of the CAS, it appears that he was never fond of putting such priorities into concrete action - a task which has to a large degree fallen on his successor Zhou Guangzhao.

After the question of basic policy priorities had been settled in favour of what we might term mission-oriented research and development by the »draft outline« of 1981, there remained the problem of reforming the 
management of S\&T in order to put such priorities into action. In essence, there were two problems: firstly, resolving the inefficiency of centralized management of research and, secondly, finding alternative means of linking research with production. Management reform would require a more substantial dissociation from the Soviet model with all its inherent contradictions and alienation from the productive system.

The ideas which were eventually endorsed by the CCP Central Committee in its "Decision on the Reform of the Science and Technology Management System « of March 1985 were, to a large degree, a victory for the economistic position with its new radical program. These ideas reflect the belief of China's reformers that a fair dose of market forces would cure the «plan« patient. Such ideas were inspired - literally, it turns out, through overseas Chinese scientists - by the liberalist image of the driving forces of innovation in the United States. It is likely that there was also a basic misunderstanding of the way in which science and technology had been utilized to boost economic development in Taiwan.

The draft of the decision was compiled in its final version after a rather long period of discussion, both within and outside the party. In the end, the document contains a compromise between the economistic and the bureaucratic models. It confirmed the new concepts of technology as a commodity, the funding reforms, the need to strengthen industrial research, and the efforts to encourage mobility among researchers which had become the hallmark of the economistic approach. Simultaneously, however, there were several paragraphs indicating a significant reluctance against relaxing control over projects of national priority (including, of course, defence) which were the main concern of the bureaucratic approach. Thus, in the course of reorganizing central administration, a call was issued for a strengthening of macro-management of science and technology.

The decision was adopted during a period when optimism still reigned concerning the results of economic reforms; particularly since the new agricultural policies had generated spectacular growth rates in the early 1980s. This optimistic sentiment appears to have reduced direct opposition in the Central Committee with regard to the more controversial elements of the decision. We may also assume that the conflicts of interest which erupted between Deng Xiaoping, $\mathrm{Hu}$ Yaobang, and eventually Zhao Ziyang about the extent and political consequences of reform were still dormant. 
During the second half of the 1980s, however, we have witnessed a retreat from the market-oriented aspects of the decision. As the practical consequences of new, innovative forms of technology transfer and entrepreneurship became apparent in 1986, brakes were applied by the central authorities. At the same time, the scaled-down eight-year plan for science and technology was completed, and the results were widely publicized, thus providing an opportunity for advanced research institutions such as the Chinese Academy of Science to lobby for new support. Preparations for a new five-year plan with many high technology projects provided further impetus to the process of lobbying, and the distinguished scientists of the academy and other institutions which were threatened by the funding reforms appears to have successfully persuaded Deng Xiaoping that such investments in advanced research were justified. Even Zhao Ziyang reluctantly postponed further cuts in operational budgets, one of the most controversial policy actions initiated under the reforms.

A typical example of the high-tech scientistic lobbyists' efforts to preserve large chunks of central support for their basic research was the publicity developed over experiments in superconductivity, which were announced with great enthusiasm in 1987. In terms of experimental results, the Chinese research on superconductivity was comparable to the most advanced Western and Japanese counterparts, although the practical commercialized applications seem nowhere in sight. In this event of symbolic significance for Chinese nationalism, strong pressures for support to institutions of advanced research were manifest and, judging from the experience of recent years, this lobbying was basically successful.

In the light of events since Spring 1989, it appears that, in addition to the scientistic lobbying, the economistic reforms had to face a severe militarist reaction to reforms which were gaining support after 1987, and that Premier Li Peng has acted as the focal point of such resistance. In some of the few public statements which Li Peng has made since Zhao Ziyang was purged, the theme of reform has been toned down considerably. In this view, the reforms have »basically been successful « - i.e. terminated - and there remain merely two issues to solve: one is the dilemma of serving the immediate needs of national economic construction or the long-term developmental needs; the other is the relationship between basic and applied research. In Li Peng's view, although the majority of efforts should go into applied research, there are elements of basic research which do not 
provide immediate economic results but which cannot be ignored.

To sum up this brief review of the political fate of S\&T policy reforms of the 1980s, we would argue that once the conflicts of ideologist vs. neutralist positions were over, S\&T policy developed in response to three basic philosophies - »bureaucratic, « »scientistic, " and »economistic - which increasingly showed signs of being rooted in organizational or sectorial lobbying. The economistic approach, which pushed reforms forwards in order to generate widespread innovation useful for China's economic development, made a bold attempt to follow up the decision of March 1985, but have been faced with outright resistance from the scientistic and gradually also from the bureaucratic camps, has reached the point where barriers to further reform seem impossible to surmount. The bureaucratic mode of S\&T management, featuring only incremental changes in relation to the basically ineffective Soviet model, now appears to occupy the main theatre of S\&T policy making.

\section{Money}

Reforms in the funding system have been the most important operational change introduced in recent years. The new funding system aims at introducing what the Chinese leadership terms «economic levers" into science and technology management, in order to make effective use of research resources.

The old funding system was based on fixed quotas. The central government controlled the allocation of annual operating budgets to independent research and development units under its jurisdiction, i.e., above municipal and provincial levels. These allocations depended mostly on the type of institute supported, the size of its staff, etc. The quantity and quality of projects were generally not evaluated, neither was there any correlation between funding and performance in terms of economic or social benefits. One gathers the impression that the old funding procedures paid little attention to the academic merits and feasibility of projects either. In short, research institutes appears to have been ineffective because they were never exposed to pressure in order to make their activities more responsive to economic and social demands.

Linking the supply of funds to fulfilment of specific research tasks was therefore seen as the key to invigoration of the S\&T system. Accordingly, the funding reform has shifted the sources of research money into three 
different avenues: government contracts, contracts with industry, and funding from research foundations.

The most important source of research funding remains government allocation, a total of 6.7 billion yuan which was almost two-thirds of the 11.4 billion yuan spent during 1987 as R\&D expenditure for civilian purposes in China. ${ }^{6}$ A system of bidding for government research contracts has presumably made the allocation procedures more competitive, and those who receive money are subject to more stringent control.

Contracts with industry and other organizations have become the second largest source of funding. Income from lateral linkages (as opposed to »vertical « source of income, i.e., allocations from the government) grew from 2.7 billion yuan in 1986 to 3.6 billion yuan in $1987 .{ }^{7}$ By the end of 1987, almost half of the institutes are said to have reduced the requirements for government funds, while 13 per cent were independent of operating funds from the government. Many research institutes under industrial ministries have cut 40 per cent of their state budget allocations.

Funding of basic research and advanced applied research is increasingly supposed to take place through the science foundation. The origins of the foundation goes back to May 1981, when the CAS Academy Affairs Committee suggested that a foundation should be set up in order to develop basic research. The CAS Foundation subsequently set up with the approval of the State Council provided funds amounting to 132 million yuan for 3246 projects from 1982 to 1984 . After this experimental phase, the National Natural Science Foundation of China (NSFC) was established in February 1986.

Government allocations are the main financial source of NSFC, although it also accepts donations from individuals and institutions at home and abroad. Everyone capable of engaging in and having conditions to do basic or applied research is free to apply for financial assistance. Applications will be evaluated through peer review, and it is believed that this procedure will ensure that the best applications will be the first to receive support. In promoting the peer review system, the foundation is a new departure from China's hierarchical structures, where age and political clout have usually been decisive in determining who should get support.

The reform of funding system naturally generates a lot of controversy. In particular, scientists from CAS were almost totally against the central decision. They complained that the government was short-sighted and only wanted to get short-term benefits from technical development and serv- 
ices instead of long-term scientific and technological advance. They argued that reforming the funding system would destroy basic research and broaden the gap with advanced countries.

A number of China's famous scientists who were trained abroad, and who are used to doing basic research geared to the forefront of international research, accordingly stepped up pressure on the government to keep their position in the international science and technology field. Thus these scientists managed to use their prestigious position to boost basic research. The 'Baliusan' High Technology Plan (Baliusan refers to March 1986, when the plan was adopted) can thus be seen as a product of a compromise between the Communist Party and the scientists in terms of reform of the funding system, in order to meet the demand of scientists doing basic research. The 'Baliusan' plan includes almost all the advanced science and technology fields: bio-technology, aeronautic and space technology, information technology, laser, automation technology, energy and new materials. The budget for this high technology adventure is reportedly around 10 billion yuan. Such expenditure is, however, negligible in international comparison and although there have been official press reports concerning the successful implementation of the plan, the prospects for large-scale economic benefits seem meagre.

\section{People}

Effective use of talented people is a pressing problem in the reform of the science and technology system in China. Deng Xiaoping has reportedly stated that »in restructuring the economic system, what is most important and what I am most concerned about is talent, in restructuring the science and technology system, what I am most concerned about is still talent." Former premier Zhao Ziyang has also been a strong proponent of reforms that would increase the rational utilization of scientists and technicians. ${ }^{8}$ The economistic camp has identified two major defects in China's present system of personnel management. The first problem is the lack of motivation on part of many educated people created by the misallocation through the central administration of the assignment of graduates. The second problem is that »unit ownership, «i.e., the tendency of research units to hoard educated people regardless of how well suited they are for their particular assignments, creates strong imbalance in the sectorial and geographical distribution of scientists and engineers. 
In the past, industrial and economic policies gave priority to providing qualified scientists, engineers and technicians to the military industry, followed by heavy industry and with light industry and agriculture trailing well behind. Therefore, among the 851.000 engineering and technical personnel working in the industrial departments in 1978 , only $14,5 \%$ were employed in the light industry while $85,5 \%$ were placed in the heavy industry. For every 10.000 S\&T workers in China, only three work in agriculture. The entire agricultural system reportedly only has 441 senior agronomists, thus occupying $0,12 \%$ of the contingent of 36.000 agricultural scientists. There is evidently a need to transfer at least part of the personnel resources to sectors such as light industry and agriculture which are in dire need of technological change.

In order to create a more even geographical distribution of manpower, the Chinese government have sought to provide some incentives for those people who were willing to be transferred to remote areas and to the countryside. These incentives included higher wages, more holidays during the year, better living conditions, better schools for their children, or even offering to bring wife and husband together. Because of the strict Chinese residence register system, wife and husband often have to live in separate localities for a very long time, occasionally all their life, so that the latter incentive would seem very beneficial to some people. People were also entitled to retain their urban registration and residence card and be guaranteed that they can return to their original place of residence after a fixed period of time.

Such incentives appear to have offered some attraction during the early years of reform. With the emergence of jobs in non-governmental institutes, suburban town enterprises, and in particular administrative services, science and technology staff have been quick to realize that they can get better paid and receive more powerful jobs without having to go to such dreaded places as the frontier areas or the countryside. Accordingly, as the reforms causing a somewhat more market-oriented mobility of qualified people have gained ground, the incentives set up by the government do not achieve much any more. Table 1 shows a matrix of the geographical distribution of personnel flow, and clearly indicates that movement is still away from the inland or remote areas towards the coastal region. 
Table 1. Matrix of S\&T Personnel Flow (1984-1987)

\begin{tabular}{lccc}
\hline From & \multicolumn{3}{c}{ To } \\
\hline & $\begin{array}{c}\text { Coastal } \\
\text { region }\end{array}$ & $\begin{array}{c}\text { Inland } \\
\text { region }\end{array}$ & $\begin{array}{c}\text { Remote } \\
\text { areas }\end{array}$ \\
\hline Coastal region & 15,365 & 5,967 & 1,062 \\
Inland region & 27,106 & 15,543 & 3,108 \\
Remote area & 15,799 & 11,411 & 2,070 \\
Source: Keji renyuan liudong taishi baogao (Beijing: Mimeo, May 1988). \\
\hline
\end{tabular}

In terms of sectorial distribution, the record appears to be equally disappointing. Table 2 shows that the actual direction of personnel flow is largely inconsistent with the alleged goals of the reform. People seem to leave state-run institutes, universities and large-scale enterprises in great numbers only to find employment in other governmental organizations. Generally, few qualified S\&T staff wish to find employment in nongovernment units because such employment is full of uncertainties.

Table 2. Trend of S\&T Personnel Flow

(No. of people, percentage of total S\&T Staff)

\begin{tabular}{|c|c|c|c|c|c|c|}
\hline & \multicolumn{2}{|c|}{1984} & \multicolumn{2}{|c|}{1985} & \multicolumn{2}{|c|}{1986} \\
\hline Research & out & $\%$ & out & $\%$ & out & $\%$ \\
\hline Institutes & 17,000 & 3.27 & 22,300 & 4.14 & 15,400 & 2.13 \\
\hline $\begin{array}{l}\text { Institutions } \\
\text { of Higher Education }\end{array}$ & 11,400 & 2.43 & 12,300 & 2.46 & 9,700 & 1.83 \\
\hline $\begin{array}{l}\text { Large and } \\
\text { Medium-sized } \\
\text { Enterprises }\end{array}$ & 70,200 & 2.63 & 70,500 & 2.54 & 51,100 & 1.76 \\
\hline $\begin{array}{l}\text { Total } \\
\text { Source: Keji reyuan liudon }\end{array}$ & $\begin{array}{r}98,700 \\
\text { taishi baog }\end{array}$ & 2.70 & 105,200 & 2.76 & 76,400 & 1.90 \\
\hline
\end{tabular}

We may conclude that, in contrast to the stated objectives of the economistic model regarding labour mobility for S\&T staff, the actual migration patterns are characterized by the following features:

1. A large number of S\&T personnel leave large and medium- sized enterprises, more than those who leave research institutes or universities.

2. A high proportion of the flow is away from remote areas. 
3. Few qualified S\&T personnel wish to leave permanently for a job in nongovernmental enterprises.

These trends reflect the fact that risk-aversion and a search for the most prestigeous places to work are still the actual core of job mobility incentives in China. The bureaucratic camp has reacted to this contradiction by a reestablishment of more stringent administrative job allocation measures. The situation by the end of the 1980s was again in a deadlock.

For people already with permanent posts the situation may be alleviated by spare-time or part-time work, i.e. «Moonlighting«. For intellectuals the new opportunities to develop prosperous side-line activities may have been the most gratifying new dimension introduced into China's employment practice. The basic concern about spare-time employment has been how to provide adequate material incentives to scientists and engineers while limiting their earnings in order to avoid jealousy from their colleagues and party cadres. In fact, such «jealousy « has caused trouble for many people with spare-time jobs. Several cases have been announced where people engaged in spare-time work were accused of economic crimes and of stealing research materials.

In order to create more precise guidelines, the SSTC issued a circular in June 1985 which stated that »we shall permit science and technology personnel to take on proper concurrent work or after-hours intellectual work, so that the potential that we have in our scientific and technical personnel is brought into full play. «Meanwhile, institute directors were advised to make some important distinctions: 1) a distinction between people who complete their primary task and those who «unscrupulously neglect their primary work to seek personal profit elsewhere «; 2) a distinction between people who accept contracts with the prior approval of their principal employers and those who "simply run off without taking leave and grab extra income by hook or by crook. «

To the outsider, this simply suggests that crooks in the S\&T institutions should be kept at bay, but of course in actual practice leaving the judgement of »healthiness « of such activities to institute directors has tended to make spare- time work more difficult. In addition, public authorities were becoming interested in these activities, and the taxation rate on income from spare-time work has, for instance, been raised on three occasions in Shanghai. 


\section{Controversial Enterpreneurship}

Entrepreneurship, in the form of leaving one's unit in order to set up a new firm, is probably the most radical approach to the problems created by the old S\&T system. It is by no means an easy decision, since a departure from the safety of permanent posts, housing schemes, etc. entails substantial risk. Entrepreneurs everywhere in the world face such risks and barriers and, in many ways, Chinese entrepreneurs resemble their colleagues in other countries in terms of social marginalization. In the past, it was virtually unthinkable that a Chinese scientist would become a businessman.

The Chinese leadership seemed, however, committed to supporting such entrepreneurship, and made a point of encouraging experimental forms of new technology-based enterprises in the Decision of March 1985. As we shall see below, a substantial number of people responded positively to this high-level support; many institutes also decided to jump into some form of collective entrepreneurship by establishing new companies.

The most well-known site for such entrepreneurship is the «Electronics Street« (dianzi jie) in the Zhongguancun area of the northwestern suburbs of Beijing. ${ }^{9}$ This area, which is also the site of many advanced research institutes in China, has become the breeding ground for a large number of so-called S\&T firms ( $k e j i$ qiye), including several which have won fame at home as well as abroad, such as the Stone Computer Company.

The fate of the Electronics Street and its entrepreneurial spirit is, in many ways, symptomatic of the way in which reform has proceeded in China. Most of the firms in the area were set up during the »overheated « days of 1984-85 and have flourished since with annual growth rates of more than 100 percent. They became the focus of controversy in 1987, when it became clear that these firms were far more effective - at least in terms of making profit - than most state-operated units. A major investigation was then carried out in early 1988 at the initiative of leading members of the CCP Central Committee. The report from this investigation seems to have settled the doubts which people like Zhao Ziyang may have had regarding how "healthy" the firms were, although more conservative adherents of the scientistic and militarist outlook certainly retained their scepticism. In spite of the apparent peace concluded with the bureaucratic sceptics within the party and among higher authorities, mistrust nevertheless continued to exist in many quarters of society. The success of the products and services which these firms offered to the market remained, in the eyes of many, a mere expression of salesmanship rather than their technological 
level. In addition to the contempt towards such commercial flair which is a distinctive feature of both traditional Chinese Confucian values and more recent Communist dogmatism, there was a fear of the political consequences of private enterprise. There was an enfant terrible buried somewhere in most of the entrepreneurs of the Electronics Street, and for some it became a political cause to defend the liberty just acquired. A spectacular climax of this political challenge was when the President of the Stone Group Corporation, Wan Runnan, came to the support of student demonstrators in Spring 1989, and had to escape to the United States and France after the crackdown.

\section{Big Business}

The history of new technology firms in the Electronics Street dates back to a "Service Department for the Development of Advanced Technology" which had been created in 1980 by a group at the Chinese Academy of Sciences, led by Chen Chunxian from the Institute of Physics. Inspired by visits to the Silicon Valley and Route 128 in the US, this bureau was an attempt to combine R\&D with production. Chen Chunxian's initiative was discussed by Hu Yaobang and other members of the CCP Central Committee in January 1983, whose conclusion was an approval of the "new road taken. "In April 1983, an independent unit was formed under the name "Huaxia New Technology Development Institute."

A large number of new firms were set up in the following years, and pioneers such as Chen Chunxian's outfit became small in the shade of a core group of very prosperous companies. By 1987, eight companies led by newcomer »Stone « had captured most of the market for micro-computers in China, recording a combined annual turnover of 680 million yuan (RMB).

Table 3. Electronics Street: Number of Firms and Turnover

\begin{tabular}{lccccc}
\hline & 1983 & 1984 & 1985 & 1986 & 1987 \\
\hline $\begin{array}{l}\text { No. of firms } \\
\begin{array}{l}\text { Turnover } \\
\text { (mill. yuan) }\end{array}\end{array}$ & 11 & 40 & 90 & n.a. & 148 \\
$\begin{array}{l}\text { Source: Xiwang de huoguang (1988). } \\
\text { n.a. }\end{array}$ & 18 & 140 & 350 & 900 \\
\hline
\end{tabular}

The most conspicuous aspect of the firms in Electronics Street is their explosive growth in sales. The turnover of firms in that area rose from 18 
million yuan in 1984 to over 900 million yuan in 1987, constituting more than a third of the total social income of the Haidian district. The turnover rose at a much faster rate than the number of firms, as shown in table 3 above.

Almost half of the 148 firms are established or associated directly with the Chinese Academy of Sciences or its institutes. Nearly a third belong to organizations of the Haidian district, while the remaining 20 per cent have been established by ministries, universities or the municipal authorities.

More than two-thirds of the firms are collectively owned, some with participation by state-owned units while other firms are genuinely run by the local people (minban). More than 20 percent are actually set up and financed by state-owned units, which affect their management style considerably. Private entrepreneurship at the Electronics Street has caught the attention of many observers both within and outside China, but with limited access to sources of capital outside the realm of state-operated units it is no wonder that few firms boast of their independence from direct intervention by some authority of the central or local government.

The difference between firms run by local people and those run by stateowned units is that the former are more profitable; but still manage to pay less tax. The table below indicates that the firms run by the local people tend to require less investment and reap higher profits per invested yuan than those which are run by the Chinese Academy of Sciences.

Table 4. Firms Run by the People and by the Academy: A Comparison of Performance (yuan).

\begin{tabular}{lrr}
\hline & $\begin{array}{r}\text { Firms run by } \\
\text { the people }\end{array}$ & $\begin{array}{r}\text { Firms run by } \\
\text { the academy }\end{array}$ \\
\hline Initial investment & $5,900,000$ & $9,900,000$ \\
Number of employees & 1,914 & 556 \\
Turnover per employee & 355,000 & 324,000 \\
Profit per employee & 28,200 & 36,700 \\
Tax paid per employee & 11,400 & 45,600 \\
Accumulated fixed assets & 13,800 & 25,200 \\
Profit per invested yuan & 9.15 & 2.06 \\
Tax per invested yuan & 3.69 & 2.56 \\
Fixed assets per invested yuan & 4.46 & 1.41 \\
Source: Xiwang de huoguang, p. 48. & & \\
\hline
\end{tabular}

The economic achievements of the entrepreneurial firms - the vast majority of which have been spin-off activities of the Chinese Academy of Sciences - have been remarkable in the light of the aloofness generally associated with researchers from the Academy. It has been argued that 
this aspect is particularly noteworthy for research institutes normally working under the industrial ministries which, in principle, should be even better qualified to set up such firms. The explanation seems to lie in some kind of overseas experience. For example, Wan Runnan, the founder and now former director of the Stone Corporation, had studied in the United States and obviously received many new ideas from that visit.

\section{Technological or Mercantile Entrepreneurship}

There have been plenty of grievances from scientists - particularly in the academy - that these firms were not really engaged in technological development, but only engaged in marketing of high-tech products from abroad. In other words, the entrepreneurs of the Electronics Street were denounced as clever salesmen. The implication is, of course, that such mercantile entrepreneurship is demeaning for an intellectual; one can sense the presence of a revoked ghost from the traditional attitudes of the Chinese intellectual elite. In addition, however, the profitability of entrepreneurship in Zhongguancun had also come up against a more recent dogma in Chinese society - the "red eye disease of jealousy of the wealthy.

Table 5. Breakdown of Income for Firms in Electronics Street (thousand yuan, per cent)

\begin{tabular}{lrrrr}
\hline Year & $\begin{array}{r}\text { Technical } \\
\text { Services }\end{array}$ & Production & Marketing & Total \\
\hline 1984 & 7627 & 1310 & 26918 & 35890 \\
& $(21.3 \%)$ & $(3.6 \%)$ & $(75.0 \%)$ & \\
1985 & 27110 & 8432 & 81506 & 117107 \\
& $(23.1 \%)$ & $(7.2 \%)$ & $(69.6 \%)$ & \\
1986 & 5113 & 2785 & 13859 & 21757 \\
Jan-Mar & $(23.5 \%)$ & $(12.8 \%)$ & $(63.7 \%)$ &
\end{tabular}

Note: Statistics based on 31, 109, and 68 firms in 1984, 1985, and 1986 respectively.

Source: Xiwang de huoguang, p. 129.

To a large extent the allegation that the entrepreneurs had achieved more in terms of salesmanship than in terms of technological innovation is correct. Table 5 shows that in $198475 \%$ of the firms' income came from mar- 
keting. During 1985-86 this share has declined, and more income is now based on the firms' own products, which presumably include indigenous design. Nevertheless, the income related directly to technical consulting, etc. still occupies approximately one quarter.

\section{Conclusion}

In this paper we have tried to set up a very simplified scheme of labelling different political outlooks on China's science and technology policy. This was done mainly in order to investigate and understand the fate of the reforms which have been introduced during the 1980s. Our interpretation is that these reforms have been undermined both by the emergence of a wide range of side-effects and - more importantly, in our view - by the lobbying of vested interests in the »old « system, i.e. the scientists and the militarystate establishment.

The reform of the funding system has, in our view, been fairly successful in terms of broadening the range of financial resources for S\&T and in providing an impetus for research institutes to seek research and development tasks which are potentially interesting to customers in the government and industrial enterprises. There has been a limit to how far one could go in this direction, however, and the criticism mounted by scientists against the full-blown implications of the reform during the late 1980s was largely effective in bringing the process to a standstill. The new diversity of funding sources has brought new possibilities for Chinese scientists to set autonomous priorities. Whether the present leadership is willing to accept this diversity in the long run remains an open question.

The attempt to improve the utilization of scientific and technical talent by larger mobility does not appear to have resulted in the kinds of flow of people that the government wanted to promote in the first place. Consequently, there has been a great number of difficulties in implementing the reform, and the effects which would have come about have largely been foregone.

The most successful result of reform has, in our view, been the encouragement of technological entrepreneurship. The irony of it is that the current leadership finds it extremely difficult to accept the implications of this success. The scepticism of bureaucracy towards the new-fangled electronics firms in Zhongguancun was temporarily put to rest after an investigation in 1987-88. But the active role of many entrepreneurs - and in partic- 
